\title{
Drift Chamber Tracking with Neural Networks
}

\author{
Clark S. Lindsey, Bruce Denby and Herman Haggerty \\ Fermi National Accelerator Laboratory \\ P.O. Box 500, Batavia, Illinois 60510
}

October 1992

Submitted to IEEE Transactions on Nuclear Science, Special Issue for 1992 Nuclear Science Symposium 


\section{Disclaimer}

This report was prepared as an account of work sponsored by an agency of the United States Government. Neither the United States Government nor, any agency thereof, nor any of their employees, makes any warranty, express or implied, or assumes any legal liability or responsibility for the accuracy, completeness, or usefulness of any information, apparatus, product, or process disclosed, or represents that its use would not infringe privately owned rights. Reference herein to any specific commercial product, process, or service by trade name, trademark, manufacturer, or otherwise, does not necessarily constitute or imply its endorsement, recommendation, or favoring by the United States Government or any agency thereof. The views and opinions of authors expressed herein do not necessarily state or reflect those of the United States Government or any agency thereof. 


\title{
DRIFT CHAMBER TRACKING WITH NEURAL NETWORKS
}

\author{
Clark S. Lindsey; Bruce Denby, Herman Haggerty \\ Fermi National Accelerator Laboratory ${ }^{\dagger}$ \\ P.O. Box 500, Batavia, Il. 60510
}

\section{Abstract}

We discusa drift chamber tracking with a commercial analog VLSI neural network chip. Voltages proportional to the drift times in a 4-layer drift chamber were presented to the Intel ETANN chip. The netrork was trained to provide the intereept and alope of atraight tracks traversing the chamber. The outputs were reeorded and later compared of line to conventiondl track fits. Two types of network arehitectures were studied. Applications of neural network tracking to high energy physics detector triggen is discussed.

\section{Introduction}

With the very high erent ratea projected for experiments at the SSC and LHC, it is important to investigate new approaches to on line pattern recognition. The use of neural networks for pattern reeognition in high energy phy ries deteetors has been an ares of very active research (see review in ref. 1). Charged particle tracking with neural networks, in particular, has been utudied ertensively. A major goal of these studies in to determine whether neural networks, which have highly parallel atructures, coold provide real time pettern recognition for triggering if they were imple mented in hardware. At high energs collider experiments an interaction can prodace a great number of tracks. In the central tracking devices, close to the interaction point, the large number of track and background signals make the treck finding networks quite complicated, especially if there is track curvature due to a magnetic field. Reeurrent type network arehitectures have been the most succesufal for track finding in large central detector events[2]. However, tracking with recurrent neural networks (all neurone interconnected and weights recalenlated for each event) has only been carried ont with off line date and with simulated networks. Hardware implementation of such networks, while not impossible, appeans very difficult.

For some types of tracting chambers it is possible to apply aimpler networks that are more amenable to hard-

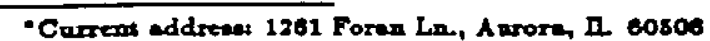

IFermilob in operated by the Universities Reventh Aswocintion ander contruet with the Department of Energy. ware implementation. Drift chambers used in muon detection syatems, for example, are typically constructed with only two to four layers of sense wires. The chambers, although covering large aress, lie far from the interaction region and so typically bave lower oceupaney rates than tracking ehambers clove to the interaction region. Since the chamben are usually outside the magnetic field and since they also only a few tens of centimeters thick, tracks crossing a muon chamber can be treated as straight lises. Osing sense wire signals from a section of auch a moon chamber, it is poarible to ase feed-forward neural networks with two layers of neurons to find track parametern. Such feed-forward neural networks are now available in VLSL. $A$ fast moon trigger syitem could be built by combining the signals from many simple hardware network, where each network is ascigned to a seetion of the detector.

Here we present results of a atudy of a VLSI neural network for finding tracks in a muon drift chamber. A prerious paper discuesed tracking in a 3-layer muon chamber[3]. Here we give reanlts for tracking in a thayer drif ehamber. We show results for a couple of different neural network architectures and diecuss possible implementation in s trigger.

\section{Intel ETANN Chip}

The Intel Electrically Trained Analog Neural Network (ETANN) has been described previounly $[4,8]$. The chip has 64 neurons or threshold amplifiers with sigmoidal response. Effectirely, howerer, there are 128 neurons since the same 64 neurons are used for both the middle and ontput layers. A signal (analog voltege $0.0 \mathrm{r}$ to $3.5 \mathrm{v}$ ) entering one of the 64 inputs is presented to a synapse. The output of the aynapse is a differential current proportional to the multiplication of the input signal and a stored weight value. The current som of the dot product of 64 inputs and 64 elements of a row of the input aynapse array is presented to the neuron corresponding to that row. In addition there are 16 internel fired (bias) voltages connected to each nenron. So each neuron sees a total sum of 80 voltage-synapee products. There are $80 \times 64=5120$ synepses in the fisst lajet array plus 5120 synapses in the second layet array.

The synapse derign is similar to a Gilbert multiplier cir- 
cuit. Here the difference in threshold roltages $(\mathrm{V} t)$ of two floating gates provides the weight value:

$$
I_{\text {noimer }} \approx\left(V_{\text {inpet }}-V_{\text {refi }}\right) \times\left(V t_{1}-V t_{2}\right)
$$

The weights values are limited to approrimately \pm 2.5 and have about 6 bit precision. Charge can be made to tunnel onto the floating gates with large roltage pulses. The synepsea are non-volatile and can remain stable for several years. There ure non-linearities in the roltage-weight multiplications, especially near the marimam weight and input voltage values[5]. However, these can be compensated for to some extent by the network training.

The neuron response, for a input reference voltage $\left(V_{\text {refi }}\right)$ of $1.6 \mathrm{v}$, is approrimated by a sigmoidal function:

$$
f_{j}\left(z_{j}\right)=\frac{3.0 v}{1.0+\exp \left(-z_{j}\right)}+0.1 v
$$

where $a_{j}$ is

$$
z_{j}=G\left[\sum_{h} w_{j k}\left(V_{b}-1.6 v\right)+\sum_{b} w_{j b}\left(V_{b}-1.6 v\right)\right] .
$$

Here $V_{h}$ is either the input voltage to the firat layer or the output roltage of the middle layer neurons presented to the second layer. The $w_{j h}$ is the reight for the connection between receiving anit $j$ and sending nnit $h$. Of the 10 internal biese $\left(V_{b} \simeq 1.0 v\right)$, seven are available for the neer (the other 8 are reserved for the initialisation of the chip by the derelopment system deseribed below.) The gain G can be varied with an erternal control rol tage and was here set at roughly 1.0. A special binary mode with fast turn on from $0.0 \mathrm{r}$ to $5.0 \mathrm{r}$ is also arailable but is not suitable as - aigmoid for back-propagation training and was not used here.

Aftez signals are presented at the inputs, the firat layer neuron outputs will reach final levels within about $3 \mu$. The first layer outputs are then available on the ontput pins (e.g. for back-propagation caleulations). Second layer processing is controlled by several external clock signals. Fint the neuron outpute are sampled and held and the inputs are dieconnected from the first gynapse arrey. Then the first level sampled outpats are presented to the second oynapue array which in tarn connects to the same neurons previoualy used for the first layer. The second layer processing tates up to $5 \mu$ for a total of about $8 \mu$ for 64 inputs, 64 neuron first layer, and 64 nenron seeond layer.

A pe-based development system for the ETANN is a vailable[6]. The system allow one to do such things as initialise the ehip, read weights or write weights to the chip, emulate the chip (e.g. with beck-propagation trainer) and do ehip-in-the-loop training (CIL). Normally one first trains with the emulator (here we used the DymaMind program[7]) and then, when the emulation performance is satisfactory, download the emulation weights to the ehip. Some further CII training is necessary since the emulation is not perfect. The synapses allow a limited number of weight ehange before becoming degraded so doing the emulation reduce the number of weight changea required. a)

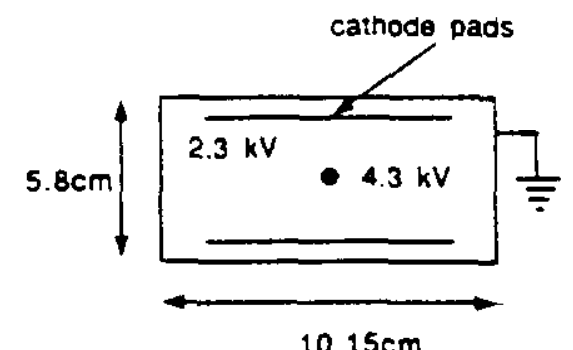

b)

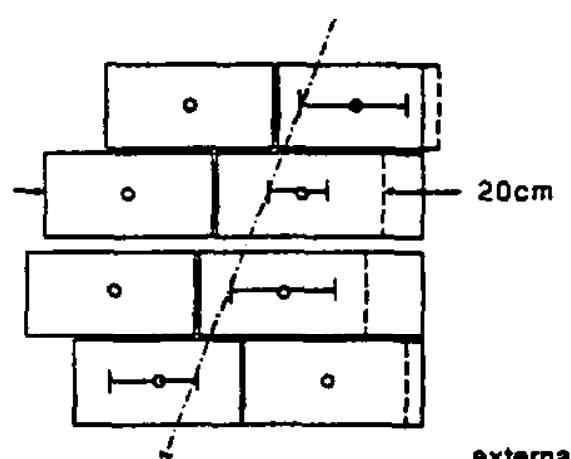

external

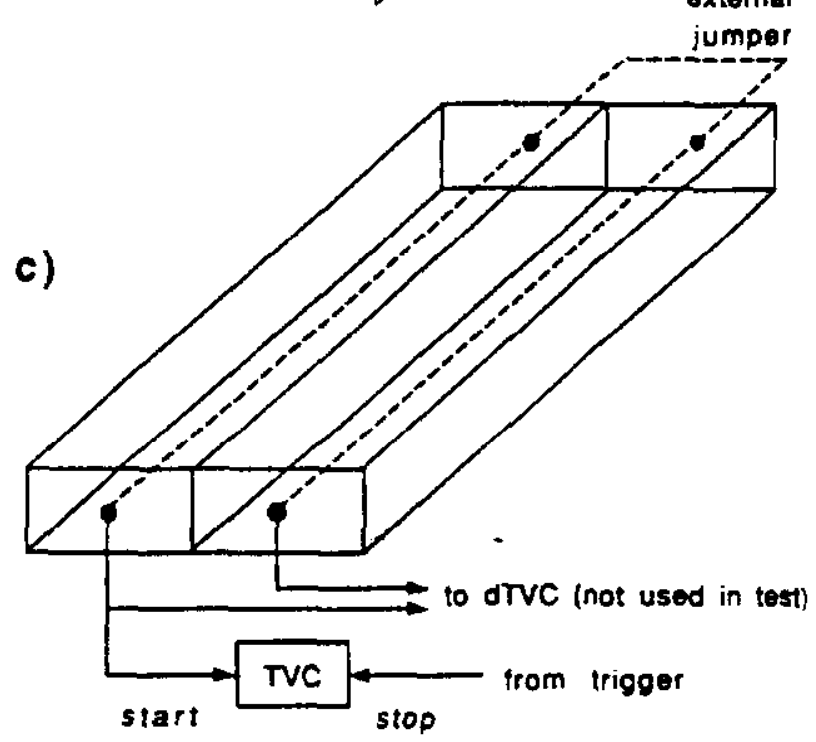

Figure 1: (a) Crose-seetion of a Do muon chamber drif cell. (b) Track through a 4layer chamber. Drifl distances, with left-right ambiguities, are shown. The right edge cells are flush. Dashed lines show normal cell width. (c) Perspective view of a cell pair showing sense wire connection at one end, drift time and signal transit time electronica at other. 


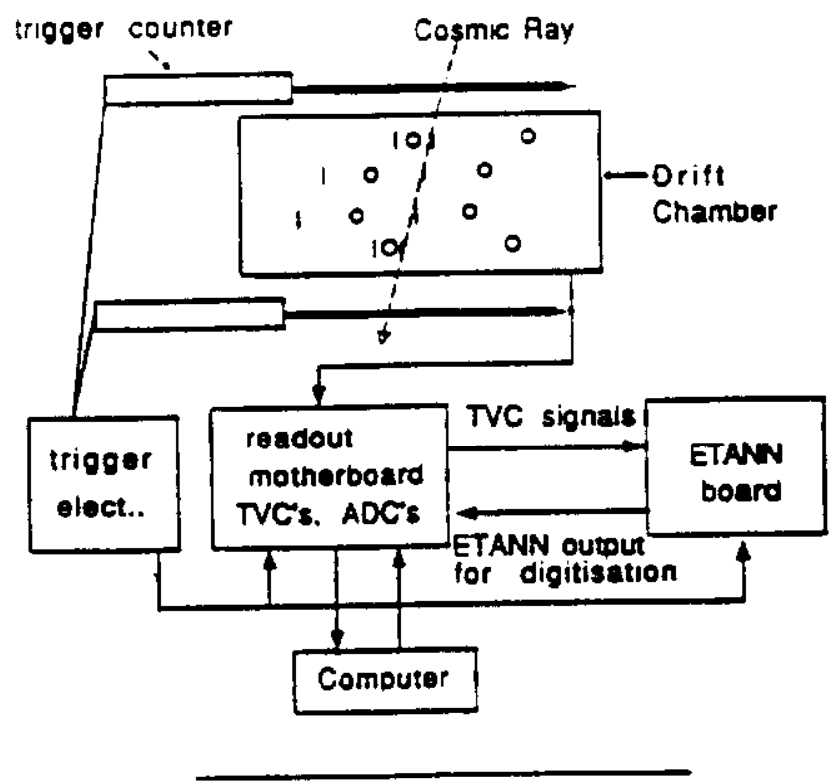

Figure 2: Teat setup for traching coamic rass.

\section{Drift Chamber Setup}

Figure 1 ahow diagrame of the moon chamber derifa aned for the DO callider detector ayntem at the Teratron [s, 9]. The eells here bem marimum drin in the seruse wire plane, with marimem drif times of about $1 \mu$. The drift timen are mearured by time to roltage convertes (TVC) and provide anviog roltage proportional to the drift times (or dintancen). Above and below the rense wire are metal pade where roltage indeced by the sense wire signal indicate where along the wire the track paned. As shown in fifure le the senes wires are connected in pain. Diflesences in rignal arrival timen at each end also indiente the longtrdinal pocition of the vire. A combination of the pad and dTVC information give an improved resolution. Here we only usod the pad signels to set latehes to indiente which of the two celle the treck traverse. The prototype chamber ased is only about a meter long 20 the transit time is negligible compared to the drift time.

Proceeding outward from the beam line, the DO central meon trigger syrtem consists of first a 4-lajer drifl chamber just outide of the central tracting chnmbers and calovimetern. Thes these is a hyes of magnetised iron and flnally two s-lajer chambers. Here we examined tracking in a prototype 4-layer muon chamber which had 8 cells arranged in the pattern found on the edge of the foll seale chambers (which can have up to 96 eell). Figare 2 show the setup used to mensure cormie ray tracke. Two scintillators proride the trigser for an erent and geserate the stop signal for the TVC's. The TVC ralues rary lineady from 3.2V for tracks at the wire to $0.0 \mathrm{v}$ at the cell wall. The TVC outpats are picked off the andog bas on the maon chambet readout board and presented to the ETANN inpris. The ehip outpats were then placed back on the bus and digitised along with the input roltages. The ADC values for the drift times and chip outpats and the pad lateh rat ves are all read out by the date sequirition syotem. Leant square fit parameters were calculated of line (the chamber recolntion is about $500 \mu \mathrm{m}$ ) from the drif chamber data and compared to the outpots of the ETANN.

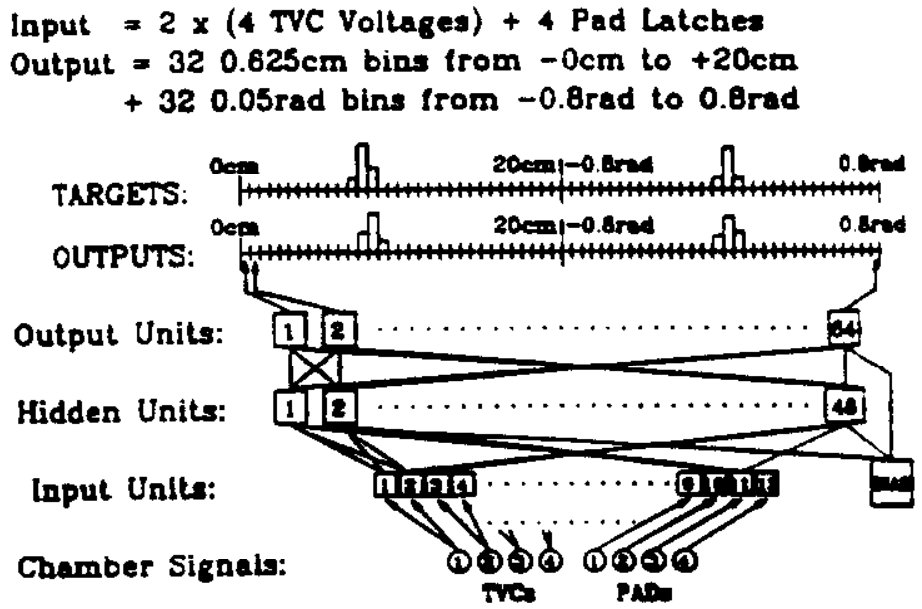

Figure 3: Two leyer feedforward searal netwotk with the dirtribuled ontput technique for giving alope and intertept of tracks from drift chamber signels.

\section{Neural Nets for Drift Chambers}

Figare 3 shom one neural network arehitecture to determine the intercept and slope of meon chamber track. TVC sigala from the four cell pain shown in flgare 1 are presented to the chip twice As mentioned above, the marimum weight is \pm 2.5 for the BTANN. Repeating the inputs effectively increases the maximnm weight to \pm 5.0 and improves the performance of the net. Aleo, pad latches from four cells are also input to the aet. Hexe, for a given cell pair, a pad lateh ralue of $3.0 \mathrm{r}$ indicate the hit is in the right hand cell, $0.1 \mathrm{r}$ indicates the bit is in the left hand cell at seen in figure 1 .

The middle lajer of the net in figure 3 has 48 neurons and the ontput lajer has 64 neurona. The intercept and the tope are expresed al bumpe in the distribution of ortput neuron ectivatione. The first 32 nenrons are need for the intercept and the second set of 32 for the slope. Each 
Input $=2 \times(4$ TVC Voltages $)+4$ Pad Latches

Output $=102.0 \mathrm{~cm}$ bins 1 rom $-0 \mathrm{~cm}$ to $+20 \mathrm{~cm}$

$+100.18 \mathrm{rad}$ bins Irom -0.8rad to $0.8 \mathrm{rad}$

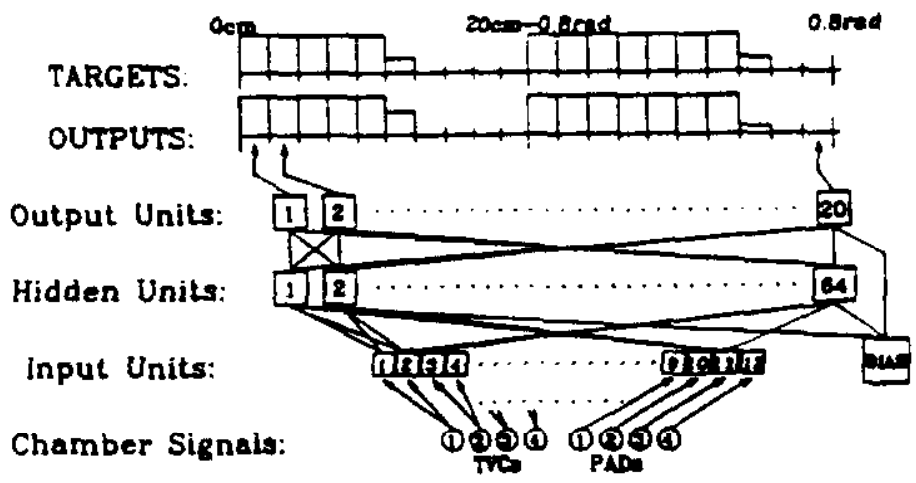

Chamber Signals:

in PAD

Figure 4: Two layer feedforward nearal network with the proportional outpet technique for firing slope and intereept of tracts from drift chrmber rigarle.

intercept nenron acts $40.0 .625 \mathrm{~cm}$ bin for the intereept range between $0.0 \mathrm{~cm}$ and $20 \mathrm{~cm}$ for the croving point in the sense wire plene of the eceond layer from the top ( $\mathrm{fg}_{\mathrm{g}}$ ure 1). The liope neurons represent 50 mand bins between $-0.8 \mathrm{rad}$ and +0.8rad, where the slope is gire as the angle from rertical. The track intercept and lope are then given as the center of Genering bowps saros 3-4 newrons. In practice the marimm outpet is found and an average over \pm 2 neurons aronnd the marimm is calculated.

The adrantage of the dirtributed ontpat method thow in figne 3 in that the averaging ore the outpets make the vines les sencitive to the jitter in single nenrons. Mno, as divcresed leter, more then one bamp ean indiente more than one porible annrer when there are ambiguitien. If combined with other informatican, wey, from another detector, having additional information ean be nefinl in some applientions[10]. The diendrantage of such a set inclade the large number of ontput nenrom needed and the need for a 2nd cirenit to ealealnte the areargen.

One could have a two outpots arehitecture where one nearon has an activation proportional to the intercept and the other nearon has actiration proportional to the slope. However, jitter, due both to electronic rariability and to imperfections in the training of the netrort, limits the precision of such a net. To take advantage of the implieity of proportional outputs bat to limit the effect of neuron jitter, we tried the architecture shown in fignre 4 (inspired by ref. 11). Here there are 10 outputa for the intercept and 10 for the slope. The rum of the first 10 ontpats is proportion to the intercept and the sum of the eceond
10 output is proportional to the alope. The final oum is then lese depeadent on small variation in the individna outpats (most actirations are either drives all the way on or all the way off.) A umming amplifier cond provide a final ingle proportiond roltage.

For each network type, fles of 20000 track patterns were generated by a Monte Carlo program that sent tracks acros the 8 cells at random anglea and intercepts (bat requiring at least one cell hit in each layer.) A piren pattern consinted of both the simulated TVC and pad lateh valnes and the target ortputs. A back-propagetion pro gram on - wortutation wan run on these flles for veveral million iterations. The resulting veight flles were then transferred to the PC emnlation program, which ran more slowly than the wortatation program bet did a more accurate simnlation of the chip. The emplation did sererd tens of thousands of back-propagation iterstions. Finally, the emalation weights were downloaded to the ehip and a fer thourand CII iterations were carried out.

\section{Results}

Fignte 5 shows fon cosmic ray tracte in the DO prototype chumber. The fit track and the neural network track are compared. The network was the distribated oatput net of figure 3. The activations of the 32 intercept nenrons and 32 alope nenrons are ale shown, along with the fit rine indicted by + grobols. In figures 5 are the bump positions mateh well with the fit parameters. In figare $6 \mathrm{~d}$ there was an ambiguity and the net gave a smaller output at the fit value than at the ambiguons track parameter. For the 3-layer network discansed in ref. 3 these ambigrou cases oceur in 5-10\% of the events. The ertre layer here reduces the ambignow cases to leas than $0.5 \%$ of the conmic ray sracts.

Figure 6ob thow dintributions of the intercept and slope vine from the fit and from the ehip. The requirmeat of hit in at fors layers eanses the raiation from uniform fist distribution. Fignres oe-d show dintribation of the differences between fit track and NX treck parameten for the dintributed network architectwre. The ifmas of the Gansine fits give resolutions of $0.76 \mathrm{~mm}$ for the intereept and 12mmd for the slope whes compare to fit tracks with ehi-square of lese than one. For all tracks the realutions are $0.99 \mathrm{~cm}$ and 14 mrad, respectively.

The proportional networt show in figure 4 was also implemented in an ETANN chip. The 10 ontputa for the intercept and the 10 ontpate for the slope were added off line rather than added by a summing umptifier. Figares 7ab show exrmpies of conmic ras tracks found by the off line fit and compared to the networl ontput. The sum of the intercept and slope outputs are illustrated below each erent pattern. The networl raloen are represented b) the length of hotisontel bare and are compared to the fit vaines. Figare $7 \mathrm{~b}$ shows the serponse to an ambigeon case. The networt oplit the difference between the two 
(a) ETANN CHUP VS CHAMBER TRACK FTT SENSE MRE - NN TRACK - - - DRIFT DISTANCE I TIT TRACK

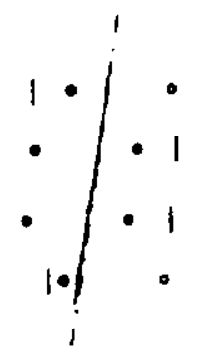

INTERCEPT

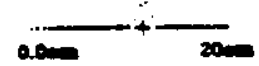

SLPE

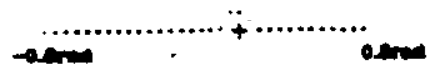

(c)

BTANN CHIP VS CHALBER TRACK FTT SEASE WIRE. - NN TRACK-·-·-・ DRITT DISTANCE । FTT TRACK

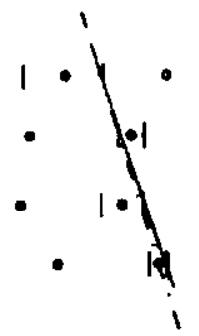

INTBRCEPT

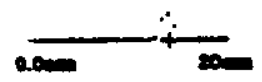

SLOPE

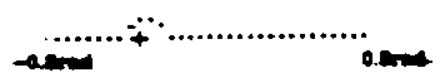

(b)

ETANN CHIP VS CHAMBER TRACK FTT SENSE WRE - NN TRACK - - - DRIFT DISTANCE! FTT TRACK

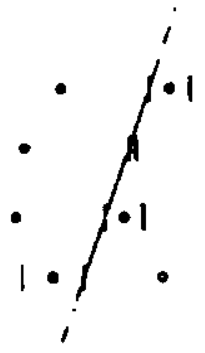

INTBRCEPT

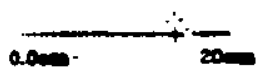

SLOPE

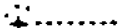

anters

(d)

ETANN CHIP VS CHAKBER TRACK FTTSENSE TIRE $\quad$ MN TRACX -.-.-・ DRIPT DISTANCE ! FTT TRACK

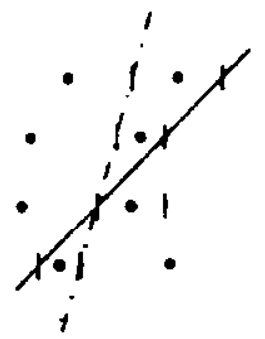

INTIRERPT

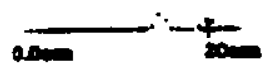

SLOPE

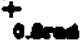

Figure 5: $(a, b, c)$ Cosmic ray events in 4-layer chamber showing the track fit and the corresponding neural network track. Below each track picture is shown the corresponding values of the output distributions of the 32 intercept neurons and the 32 slope nenrons. Also shown are fit values with + signs. (d) A case where the neural network chose a different track than the best fit. 

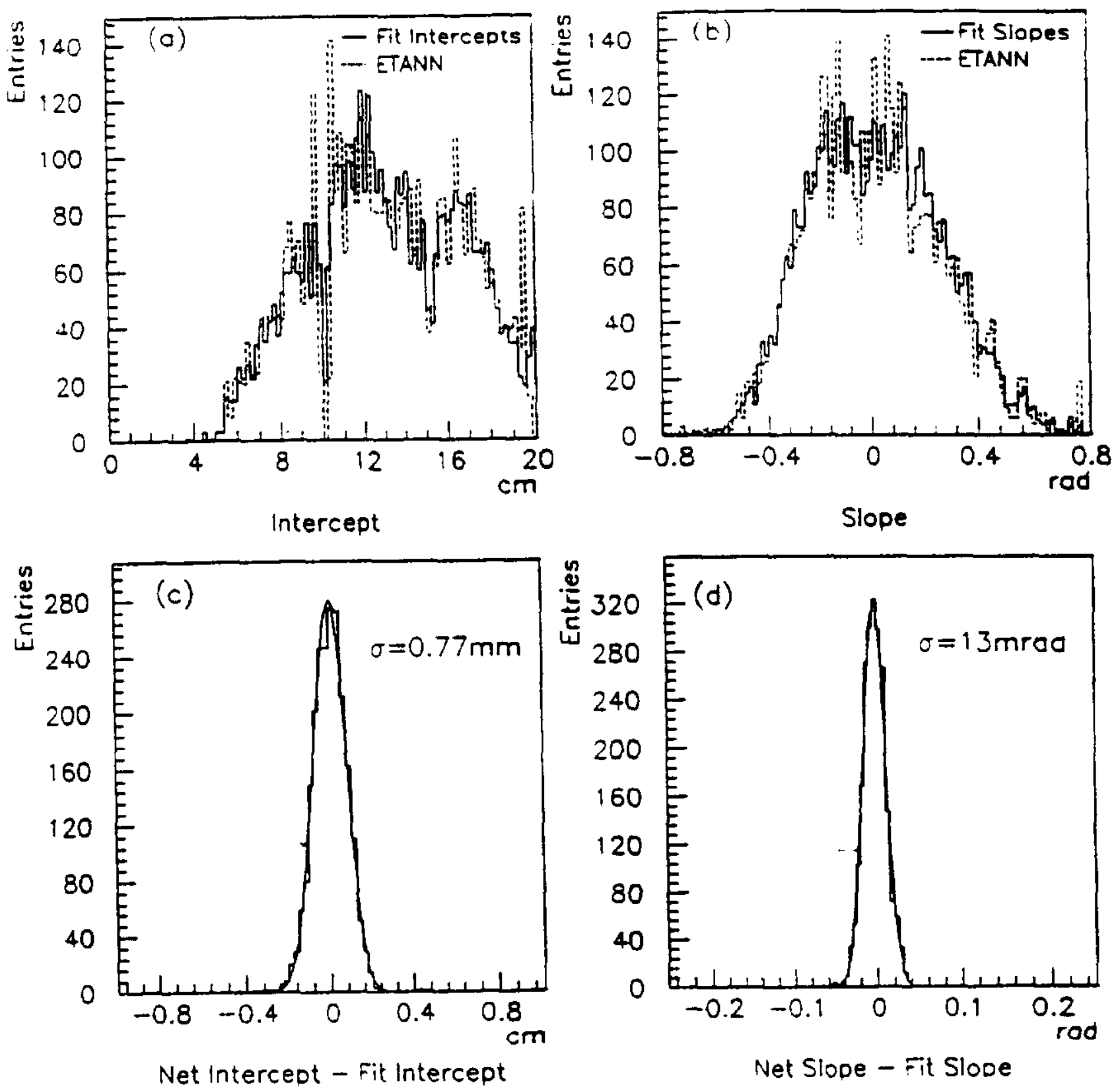

Figure 6: Distributions of (a) intercepts and (b) slopes for both fit and distributed neural network. Distributions of differences in fit and neural net (c) intercepts and (d) slopes, with Gaussian fits. 


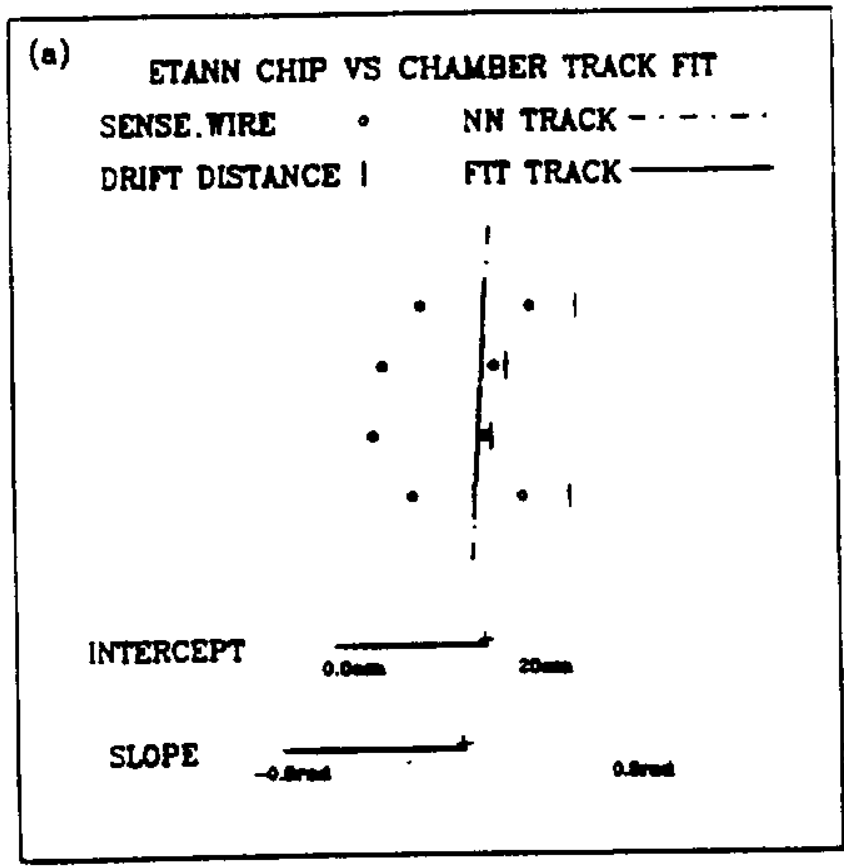

(b) ETANN CHIP VS CHAMBER TRACK TTT SENSE MTRE $\quad$ NN TRACK $-\cdots-\cdot-\cdot$
DRIFT DISTANCE ! FTT TRACK-
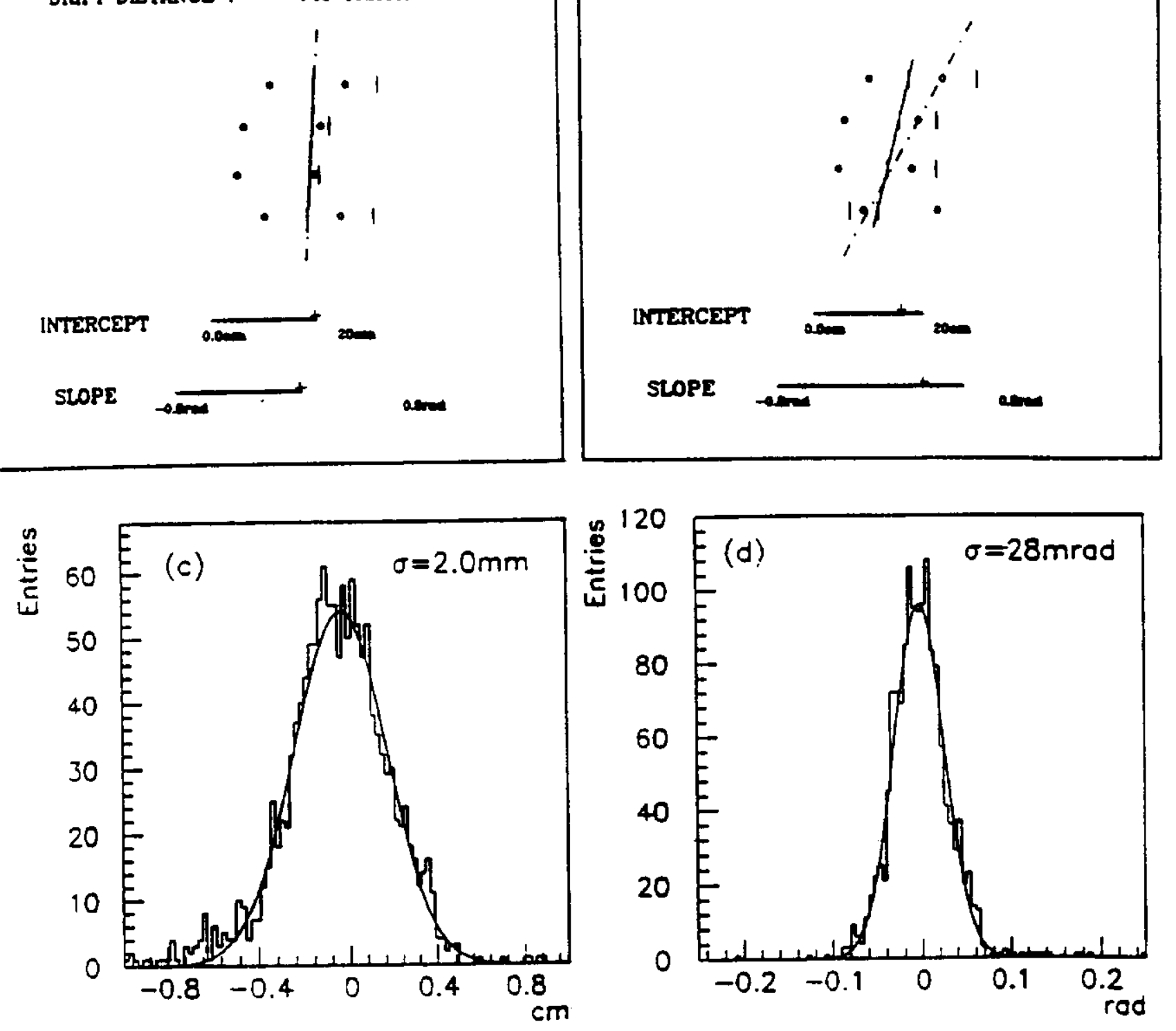

Net Intercept - Target Intercept

Net Slope - Fit Slope

Figure 7: (a)-(b) Two cosmic ray events with the fit track and the proportional net (see fig.4) track. Below each track picture are shown horizontal bars proportional to sum of each set of 10 outputs for intercept and slope, + signs represents fit values. Distributions of differences in fit and neural net are shown for (c) intercepts and (d) slopes, with fits to Gaussians. 
poerible tracks. Figure 7c-d show distributions of difterences between the network values and the fit values for the intercept and slope parameters. The resolutions are $2.0 \mathrm{~mm}(2.4 \mathrm{~mm})$ and $28 \mathrm{mrad} 30 \mathrm{mrad}$ with (without) the chi-squared cut.

\section{Discussion}

Following on previous study of 3-layet muon chamber tracting with the ETANN chip[3], we have here preseated rerolts on tracking with a 4layer moon chamber. In addition to the distribated ontput method nsed before, we have aleo tried a proportional outpnt type network. The latter give only about $2.0 \mathrm{~mm}$ position resolution compared to $0.76 \mathrm{~mm}$ for the distribated network bat it would allow for a moch implex implementation in practice.

The current DO mon trigger has an effective resolntion of about $5 \mathrm{~cm}$. Barienlly it nsea the chamber $a$ a hodoscope by looking for pain of bits in adjacent cells and doen not use drif time information[12]. The mnon trigger is in the 2nd lerel of the DO trigger system and must perform is ceveral mieroseconds. If the neural network shown here were incorporated into en upgraded minon trigger system, they would provide a great improvement in the track resoletion.

The neurel network moon trigger strateg deseribed in ref 12 would require many nearal networts each anigned to section of mnon chamber. Where the oceupaney rate is low, siganls conld be ganged together so a to use a ingle netwoth for many wires. The outpets of networts from the three ehumber of the central moon chamber would be preaented to a econd level of networks. The second level networks conid be trained, for example, to give an ontput proportional to the momentum of a track or its errspolated distance of closest approsech to the interaction paint.

For some applications of nearal network tracking one may not need the foll power of the ETANR. If a net of reights are fond stirfictory, one conld implement the netwok into a cirenit which hes fred weights made from simple resietors a discused in ref. 14. Sneh nets would be cheaper and rimpier than the ETANN eapecinlly if needed in large numbers. Also, the ETANN mas be too tow for come applications whereas these neth conld perform in mech les than a microsecond. At a prototyping tool one could nee the ETANN for finding the optimam network arehitecture (e.g. minimnm number hidden nnits needed, beat type of outpat architecture, etc.) and then use a resistor network for the final deriga.

\section{Actnowledgemente}

We give our appreciation to Gustaro Cancelo and Sten Hansen of Fermilab for their assistance. We thank Mark Holler, Finn Martin and Simon Tam of Intel for their help. Thants also to Giovanai Panletta of the University of Udine and Ken Johne of the Univernity of Arisonn. Thin research was apported by Fermi Nationw Accelere tor Lab.

\section{References}

[1] B. Denby Tutorial on Neural Network Applicatione in Bigh Energy Physics: A 1992 Perspective, to be published in the proceedings of the Second International Workshop on Software Engineering, Artificiv Inteligence, and Expert Systems for High Energy and Noclear Physics, La Londe les Maures, France in Jannary 1992.

[2] B. Denby, Computer Phyo, Commun, 49 (1988) 429.

[3] C. S. Lindrey, B. Denby, H. Haggerty, and K. John, Necl. Inst. \& Meth., A317 (1992) 346-356.

[4] M. Holler et al.,Proc. Int. Joint Conf. on Netral Networks, Waskington, D.C., (1989), vol. II, IEEE Cutalog $890 \mathrm{C} 2758$, p. 191.

[5] Date booklet for Intel 80170 NX Electrically Trainable A nalog Nerral Network, Intel Corp., Juae. 1991.

[6] Intel Corp., 2250 Miscion College Bodierard, MS SC940, Santa Clara, Ca. 95052-8125

[7] iD rnamind User's Guide, NeuroDynamix, Bouider Coloredo, 1991.

[8] D. Green et al., Nucl. Inst. \& Meth. A256 (1887) 305.

[9] C. Brown et al., Nuel. Inot. \& Meth. A270 (1989) 331.

[10] C. S. Lindsey and B. Denby, Nael. Int. L Meth, A.302 (1991) 217.

[11] T. Akbils, T. Lindblad, B. Lund-Jensen, G. Srekely, and Age Bide, preprint $A$ Bardware Implementation of as Analog Neural Network for Ganstian Peab-fitting, submitted to Nael. Inst. \& Meth. Section A.

[12] M. Fortner, A nalog Nexral Networks in as Upgreded Mfuow Trigser for the DO Detector, to be publithed in Proceeding of the Second International Wortshop on Software Engineering, Artificial Intelligence, and Expert Srstems for High Energy and Nuclear Phyrica, La Lande les Menres, France in Janant 1902.

[13] H. Haggerty, Discrete Component Bardware Newral Net for Drif Chamber Track Finding, submitsed to NSS Conference Record, 1992 IEEE Nuclear Science Sympocium. 